\title{
Breeding and Evaluating for Landscape Performance and Fruitlessness in Mexican Petunia (Ruellia, Acanthaceae)
}

\author{
Rosanna Freyre ${ }^{1,4}$ and Adam Moseley ${ }^{2}$ \\ University of Florida/Institute of Food and Agricultural Sciences, Environmental \\ Horticulture Department, P.O. Box 110670, Gainesville, FL 32611
}

\author{
Sandra B. Wilson ${ }^{3}$ \\ University of Florida/Institute of Food and Agricultural Sciences, Environmental \\ Horticulture Department, Indian River Research and Education Center, 2199 \\ South Rock Road, Fort Pierce, FL 34945
}

\author{
Gary W. Knox ${ }^{3}$ \\ University of Florida/Institute of Food and Agricultural Sciences, Environmental \\ Horticulture Department, North Florida Research and Education Center, 155 \\ Research Road, Quincy, FL 32351
}

Additional index words. hybridization, invasive plants, Mexican Bluebell, polyploidization, Ruellia simplex Wright, Ruellia tweediana Griseb., Ruellia coerulea Morong, triploids

\begin{abstract}
Mexican petunia (Ruellia simplex Wright) is a non-native plant that was introduced to Florida sometime in the 1940s and since then has naturalized in most of the state and in other southern states. Since 2007, we have developed at the University of Florida/Institute for Food and Agricultural Science in Gainesville the first Ruellia $\mathbf{L}$. breeding program aiming to develop fruitless plants with different flower colors and growth habits that will not be invasive by seed dispersal. A combination of polyploidization and hybridization methods was used. In 2011, a total of 15 plants were selected and grown in southeastern, north-central, and northwestern Florida (Fort Pierce, Citra, and Quincy) using a randomized block design with three blocks and three plants per plot at each site. Plants were evaluated monthly for landscape performance, flowering, and fruiting. Two hybrids (R10-102 and R10-108) had outstanding potential as new fruitless cultivars for the plant industry having improved landscape performance and flowering.
\end{abstract}

Ruellia L. is one of the largest genera in the Acanthaceae and consists of $\approx 250$ species of perennial herbs, subshrubs, and shrubs with mostly tropical and subtropical distribution (Ezcurra, 1993). Five species of Ruellia are native to Florida, and three non-native species are listed as naturalized in the state:

Received for publication 7 June 2012. Accepted for publication 18 July 2012

The development and evaluation of Ruellia was funded, in part, by the USDA/Tropical and Subtropical Agriculture Research (TSTAR) program and the Florida Nursery, Growers and Landscape Association

We thank Madeline Bottenhorn, Kelly Ellison, Keona Nolan, James H. Aldrich, and Brian Owens for their technical assistance; Terri A. Mellich for performing flow cytometry ploidy determinations; Zhanao Deng and Joyce L. Jones for field pre-trial of clones (GCREC, Wimauma, FL); Jingsheng Huang for help with statistical analyses; and Ken Quesenberry for helpful discussions.

${ }^{1}$ Research Scientist.

${ }^{2}$ Student.

${ }^{3}$ Professor.

${ }^{4}$ To whom reprint requests should be addressed; e-mail rfreyre@ufl.edu. chromosome numbers in several Ruellia species from Central and North America were all found to be $n=17$. Thus, this chromosome number appears to be widespread in this large and variable genus from various parts of the world (Daniel and Chuang, 1993; Daniel et al., 1984, 1990). Ruellia simplex (as $R$. tweediana) was also reported as $2 n=34$ (Piovano and Bernadello, 1991).

Ruellia simplex is found in sunny areas on periodically inundated soils in the south of the United States, Mexico, the Antilles, western Bolivia, southwestern Brazil, Paraguay, Uruguay, and northeastern Argentina (Ezcurra and Daniel, 2007). Ruellia simplex has the ability to grow in a wide range of environmental conditions, from wetlands to almost xeric (Hupp et al., 2009). It produces on average 20.6 seeds per capsule with $98 \%$ to $100 \%$ germination rate under ideal conditions of $30{ }^{\circ} \mathrm{C}$ day and $20^{\circ} \mathrm{C}$ night (Wilson and Mecca, 2003). Explosive dehiscence of the seed capsule results in seed dispersal distances from the parent plant of 2.5 to $3 \mathrm{~m}$ (Witzum and Schulgasser, 1995). Furthermore, Ruellia seeds turn mucilaginous and adhesive on contact with water and in this way can be dispersed by animals (Ezcurra, 1993). Consequently, $R$. simplex has naturalized in disturbed uplands and wetlands of seven southern U.S. states (Florida, Georgia, South Carolina, Alabama, Mississippi, Louisiana, and Texas) plus the Virgin Islands, Puerto Rico, and Hawaii (Kartesz, 2012; U.S. Department of Agriculture, Natural Resources Conservation Service, 2012).

In Florida, $R$. simplex has formed naturalized populations in 28 counties throughout the state (Wunderlin and Hansen, 2012) and is listed in 18 areas reserved for conservation in South Florida (Gann et al., 2008). Since 2001, the Florida Exotic Pest Plant Council (FLEPPC) has considered Mexican petunia as a Category I invasive plant, described as "plants that are altering native plant communities by displacing native species, changing community structures or ecological functions, or hybridizing with natives" (FLEPPC, 2011). The Institute for Food and Agricultural Science (IFAS) Assessment of the Status of Non-Native Plants in Florida's Natural Areas states that Mexican petunia is invasive and not recommended for use in the central and south parts of Florida. It is also not recommended in northern Florida unless its specified use is approved (IFAS Invasive Plant Working Group, 2011).

Invasive species damage natural areas, alter ecosystem processes, displace native species, hybridize with natives, and/or support other potentially damaging plants, animals, and pathogens (Randall and Marinelli, 1996). Destruction of native ecosystems by invasive plants is an issue of worldwide concern with consensus that early eradication is critical. In the United States, an estimated 5000 plant species have escaped cultivation and are now established in natural ecosystems. The cost associated with invasive plant damage and control is estimated at nearly $\$ 35$ billion a year and plant invasions are increasing 
at a rate of $10 \%$ annually (Pimentel et al., 2005). Conventional and new biotechnologies such as use of wide hybridization, selection and breeding for double flowers, development of triploid plants, and use of induced mutations can be used to develop new, non-invasive cultivars (Ranney, 2004). New approaches include using genetic engineering to develop "supersterile" cultivars that are both maleand female-sterile (Li et al., 2004).

Currently there are tall ('Purple Showers', 'Chi Chi', and 'Snow White') and dwarf ('Katie' and 'Southern Star' series) cultivars available of $R$. simplex in purple, pink, and white flower colors. These cultivars are propagated clonally to maintain their identity with the exception of the 'Southern Star' plants, which are propagated by seed (PanAmerican Seed Co., Chicago IL). All known cultivars are fertile, set fruit and produce viable seed, and are potentially invasive with the exception of 'Purple Showers', which does not set fruit by open pollination (Wilson and Mecca, 2003). A survey conducted in 2002 including 946 active nurseries in Florida indicated that $15.9 \%$ of them grew or sold $R$. simplex, and the total reported annual sales for this plant was estimated at $\approx \$ 12$ million (Wirth et al., 2004). Sales of 'Purple Showers' in Florida were ranked third for herbaceous perennials after pentas and lantana (Ornamental Outlook, 2009).

New, sterile Ruellia cultivars with novel flower colors and growth habits have great potential for landscape use in Florida and other U.S. southern states as an alternative to the invasive wild $R$. simplex and fertile cultivars. Since 2007, we have developed at the University of Florida/IFAS in Gainesville the first Ruellia breeding program using a combination of polyploidization and hybridization techniques. The objective of this research is directed specifically toward creating fruitless cultivars for the landscape plant industry. Plants were evaluated in multilocation trials in Florida and selections were made for potential new cultivar releases.

\section{Materials and Methods}

Polyploidization. Polyploidization experiments were performed at the University of
Florida in Gainesville between Sept. and Dec. 2008 using oryzalin on the apical meristem of seedlings as described (Jones et al., 2008). Seedlings obtained from self-pollination of $R$. simplex with four different flower colors were used: purple wild $R$. simplex, pink 'Chi Chi', white $\mathrm{F}_{2}$ plant from the cross purple wild R. simplex $\times$ 'Katie White', and an accession with white flowers with a purple center, found at McKee Botanical Gardens, Vero Beach, FL, hereafter referred to as McKee. One seedling for each line was used as a control, and six seedlings were used for each dose $(25$ or $50 \mu \mathrm{M}$ ) and application frequency (one, two, three, or four times every $12 \mathrm{~h}$ ) of oryzalin. Ploidy levels were determined on mature plants using flow cytometry as described by Czarnecki and Deng (2009) with wild $R$. simplex used as a diploid control. Plants with means for the relative DNA fluorescence curves approximately double in value than the diploid were considered tetraploid, and those with curves with means intermediate between diploid and tetraploid values were considered triploid.

Hybridizations. Hybridizations were performed with plants of different ploidies such as $4 x \times 2 x$ and $2 x \times 4 x$, aiming to obtain sterile triploid plants. Additionally, $4 x \times 4 x$ crosses were also performed. Between five and 10 hybridizations were performed for each cross. Fully expanded flower buds or recently opened flowers on the maternal parent plants were emasculated by removing the corolla and attached anthers. Immediately, the stigma was rubbed with the anthers of a flower from the paternal parent. The pollinated flower was then tagged with a plastic colored string. When the fruit developed, it was enclosed with an empty tea bag secured with a paper clip to prevent losing the seeds when the fruit ripened and dehisced.

Preliminary evaluations. Plants were initially evaluated in a greenhouse in Gainesville for growth habit, flowering, and lack of fruit formation. Some plants were propagated vegetatively and grown in field trials in Citra, FL, in the summers of 2009 and 2010, while simultaneously being maintained in the greenhouse. In Apr. 2011, 270 Ruellia clones were transplanted to a field in Wimauma, FL, for a preliminary evaluation and visual selection process for landscape performance and flowering.

Performance at multisite replicated trials. Plants were trialed in three simultaneous field experiments conducted at the North Florida Research and Education Center in Quincy, FL, at the Plant Science Research and Education Unit in Citra, FL, and the Indian River Research and Education Center in Ft. Pierce, FL, corresponding to northwestern, northcentral and southeastern Florida, respectively (Table 1). The experimental design used at each site was a randomized complete block with three blocks. Each plot consisted of three plants for each cultivar, hybrid, or mutant spaced $50 \mathrm{~cm}$ apart. At each experimental site, wild $R$. simplex and 'Purple Showers' were included as purple-flowered comparisons and 'Chi Chi' as a pink-flowered comparison. 'Snow White' and McKee were included as white-flowered and white with purple corolla tube comparisons, respectively, in Citra and Quincy but not in Fort Pierce as a result of space limitations.

Fifteen plants and five control cultivars were selected for the trials. Plants installed at all sites were propagated at the University of Florida in Gainesville. Cuttings were taken on the week of 4 Apr. 2011 with the exception of the cuttings for 'Snow White', which were taken 2 weeks later, when there were enough cuttings available. Twenty-seven cuttings per plant were stuck onto 128-cell cutting trays with Fafard 2P mix (Concord Fafard Inc., Agawam, MA; 60\% Canadian peatmoss, $40 \%$ perlite) and placed under mist in a research greenhouse. After 2 weeks, rooted cuttings were transplanted into 10-cm Ellepots (Blackmore Co. Inc., Belleville, MI) and moved to an open-sided greenhouse for hardening. Plants were hardened for 3 weeks, during which they were fertilized at each irrigation with $150 \mathrm{ppm}$ nitrogen with Peters liquid fertilizer $(20 \mathrm{~N}-$ 4.4P-166K; Everris ${ }^{\mathrm{TM}}$, Charleston, SC).

When plants were 5 weeks old, they were distributed to each of the experimental sites and then transplanted to ground beds in full sun within 1 week. The fields were either

Table 1. Coordinates, heat and cold hardiness zones, soil type, and soil test results in May 2011 of three Florida sites where Ruellia plants were evaluated.

\begin{tabular}{|c|c|c|c|c|c|c|c|c|c|}
\hline \multirow[b]{2}{*}{ Site } & \multirow{2}{*}{$\begin{array}{l}\text { Latitude/ } \\
\text { longitude }\end{array}$} & \multirow{2}{*}{$\begin{array}{c}\text { Heat zone/ } \\
\text { cold hardiness }\end{array}$} & \multirow[b]{2}{*}{ Soil type } & \multicolumn{6}{|c|}{ ppm } \\
\hline & & & & $\mathrm{NO}^{3}-\mathrm{N}$ & Phosphorus & Potassium & Magnesium & Calcium & $\mathrm{pH}$ \\
\hline Northwestern & $30.5^{\circ} \mathrm{N}$ & $9 / 8 b$ & Ruston series & 4.3 & 88 & 148 & 56 & 360 & 4.1 \\
\hline (Quincy)y $^{\mathrm{y}}$ & $84.6^{\circ} \mathrm{W}$ & & $\begin{array}{l}\text { Fine loamy, siliceous, } \\
\text { semiactive }^{v}\end{array}$ & & & & & & \\
\hline \multirow{2}{*}{$\begin{array}{l}\text { North Central } \\
(\text { Citra })^{\mathrm{x}}\end{array}$} & $29.4^{\circ} \mathrm{N}$ & $10 / 9 a$ & Candler series & 1.4 & 189 & 82 & 25 & 369 & 4.6 \\
\hline & $82.2^{\circ} \mathrm{W}$ & & $\begin{array}{l}\text { Sand-forested, uncoated } \\
\text { lamellic quartzipsamments } \\
\text { hyperthermic }\end{array}$ & & & & & & \\
\hline \multirow{2}{*}{$\begin{array}{l}\text { Southeastern } \\
\text { (Fort Pierce) }^{\mathrm{w}}\end{array}$} & $27.4^{\circ} \mathrm{N}$ & $9-10 / 10 a$ & Ankona series & 6.6 & 92 & 75 & 117 & 590 & 5.8 \\
\hline & $80.4^{\circ} \mathrm{W}$ & & $\begin{array}{c}\text { Sandy, siliceous, } \\
\text { hyperthermic }\end{array}$ & & & & & & \\
\hline
\end{tabular}

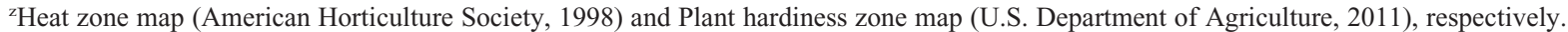

yNorth Florida Research and Education Center, Quincy (Gadsden County).

${ }^{x}$ Plant Science and Education Unit, Citra (Alachua County).

wIndian River Research and Education Center, Ft. Pierce (St. Lucie County).

vU.S. Department of Agriculture, Natural Resources Conservation Service (2012). 
fumigated or glyphosate was applied at least 3 weeks before planting, then they were rototilled, and rows were formed and covered with black woven nursery groundcover (L \& M Supply Co., Willacoochee, GA) held down by fabric pins and soil. In Fort Pierce, beds were raised $10 \mathrm{~cm}$ off the ground to facilitate drainage, whereas in Citra and Quincy, the beds were not raised. Transplanting was completed between 6 and 10 May 2011. Complete soil tests (Mehlich-III/ $\mathrm{H}_{2} \mathrm{O}$ extraction; QAL, Panama City, FL) were performed for each site; each sample was a composite collected during transplant from three locations per site. Within $3 \mathrm{~d}$ after transplanting, each plant was top-dressed with $\approx 9 \mathrm{~g}$ of the controlledrelease fertilizer Osmocote $\AA \quad(15 \mathrm{~N}-39.6 \mathrm{P}-$ 99.6K, 12-14 months, Southern formulation; Everris ${ }^{\mathrm{TM}}$ ). Irrigation was through drip tapes under the rowcovers in Citra and Quincy and on top of the covers at Fort Pierce. Irrigation was supplied as needed at each site depending on the soil type and weather conditions. At Citra additional liquid fertilizer was applied after subsequent soil test results performed every 8 weeks. Characteristics of the three evaluation sites are described in Table 1. Monthly average maximum and minimum temperatures, total rainfall, and solar radiation for the three evaluation sites and the 10-year average (recorded by Florida Automated Weather Network monitoring stations at each site) are shown in Figure 1.

Each plant was evaluated every 4 weeks, from Week 0 to 24, for landscape performance with a scale from 1 to 5 where $1=$ very poor quality, not acceptable, severe leaf necrosis or chlorosis, poor form; 2 = poor quality, not acceptable, large areas of necrosis or chlorosis, poor form; 3 = acceptable quality, somewhat desirable form and color; $4=$ very good quality, very acceptable and desirable color and form; $5=$ excellent quality, perfect condition, premium color and form. Flowering was rated on a 1 to 5 scale where $1=$ no flowers or buds; 2 = buds but no open flowers; $3=$ one to 10 open flowers; $4=11$ to 20 open flowers; $5=$ more than 21 open flowers per plant. Fruiting was rated on a 1 to 5 scale where $1=$ more than 50 fruits per plant; $2=$ 21 to 50 fruits; $3=11$ to 20 fruits; $4=$ one to 10 fruits; $5=$ no fruits.

Statistical analyses. Data were analyzed using SAS PROC GLM with mean separation using Duncan's multiple range test at $P=$ 0.005 (SAS Institute, 2004).

\section{Results and Discussion}

Ploidy levels. In 2009, a total of 14 tetraploid plants in four different flower colors was obtained. Successful polyploidization treatments were three or four applications of $25 \mu \mathrm{M}$ oryzalin or one, two, three, or four applications of $50 \mu \mathrm{M}$ oryzalin every $12 \mathrm{~h}$. The treatment of two applications of $50 \mu \mathrm{M}$ oryzalin every $12 \mathrm{~h}$ is considered optimal as a result of the ease of application. As expected, the flowers on tetraploid plants were larger than the original diploid plants
(Fig. 2). Interestingly, both 'Purple Showers' and 'Snow White' were found to be natural tetraploids as well as some accessions of South American R. simplex, previously considered $R$. coerulea. Our observations are that both the latter and 'Snow White' have leaves that are more lanceolate and lighter green than the other $R$. simplex genotypes; they have larger fruit capsules, seeds, and cotyledons; and they are also more susceptible to mite infestations in the greenhouse.

Hybridizations. In 2010 a total of 125 $4 x \times 2 x$ hybridizations was performed, and only 69 fruits $(55 \%)$ were formed and bagged. Moreover, most of the fruits aborted before harvest, and only nine fruits $(7 \%)$ could be harvested when ripe, indicating the effect of a triploid block. The use of embryo rescue could possibly be explored to obtain more triploid hybrids. A total of 96 seeds were obtained, most of which did not appear plump and normal, and subsequently only three seeds (3\%) germinated. Interestingly, ploidy levels of the resulting hybrids were one diploid, one triploid, and one tetraploid (Table 2). This suggests that the diploid was produced by haploid parthenogenesis and that the tetraploid was the result of apomixis in the maternal parent or fertilization by $2 n$ pollen. By pollen staining, we have observed that some genotypes, i.e., 'Chi Chi', produce $2 \mathrm{n}$ pollen (data not shown). Additionally, a total of $202 x \times 4 x$ hybridizations was performed. Fruiting success was $70 \%$, and
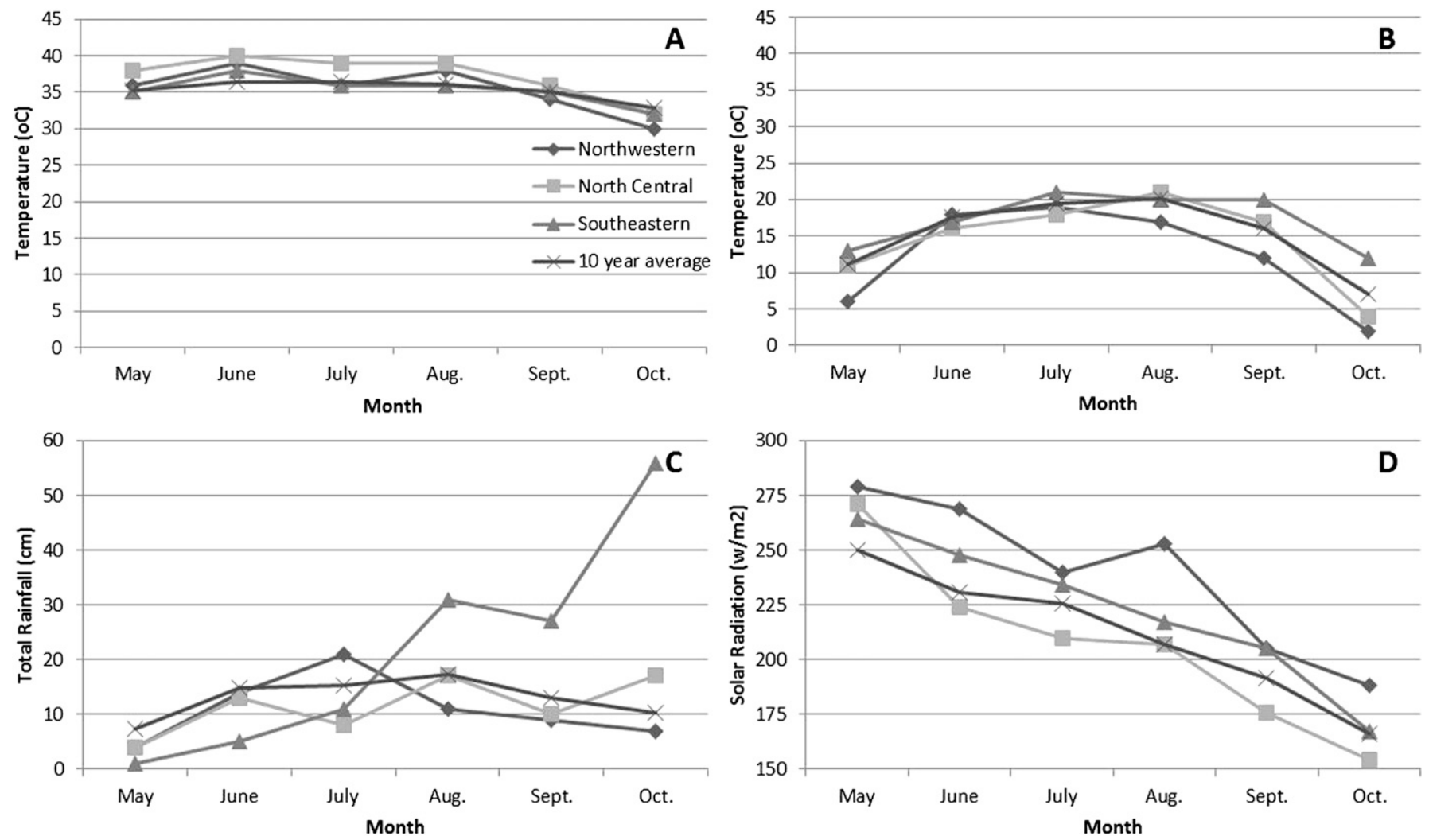

Fig. 1. Monthly average maximum daily temperature (A), minimum temperature (B), total rainfall (C), and daily solar radiation (D) from transplanting date (6 to 11 May 2011) to last evaluation date (22 Oct. 2011) at the northwestern (Quincy), north-central (Citra), and southeastern (Fort Pierce) Florida planting sites and the last 10 -year average for the three sites. 
most of the fruits could be harvested when ripe $(65 \%)$. However, although a total of 219 seeds were obtained, most of them appeared shriveled and small and none germinated (Table 2). Some $4 x \times 4 x$ hybridizations between genotypes with different morphology were also performed, a few of which were successful (data not shown).

Selection of plants for field trials. In 2010 a total of 495 plants obtained either by polyploidization or hybridizations was evaluated under greenhouse conditions for vigor, flowering, and apparent fruitlessness or reduced fruiting. Subsequently, 270 plants were selected for a preliminary spring trial for field performance at Wimauma in Spring 2011 with one replication. Finally, a total of 15 plants were selected for replicated multilocation trials.

The ploidy levels, origin, or parentage of the 15 plants is shown in Table 3 . The origin of these plants is varied. Some of the plants are tetraploid, obtained directly from oryzalin treatment. Other tetraploids were derived from $4 x \times 4 x$ crosses combining the South American accessions (previously known as $R$. coerulea) by tetraploid $R$. simplex (R10102 , R10-107). There were only two triploid plants: R7-100 was derived from a $4 x \times 2 x$ cross performed in 2007, and R10-100 was obtained in 2010, respectively. R10-100 is purple and was obtained from the cross $4 x$ white $\times 2 x$ pink indicating complex genetics of flower color. Some plants were $\mathrm{F}_{2}$ hybrids

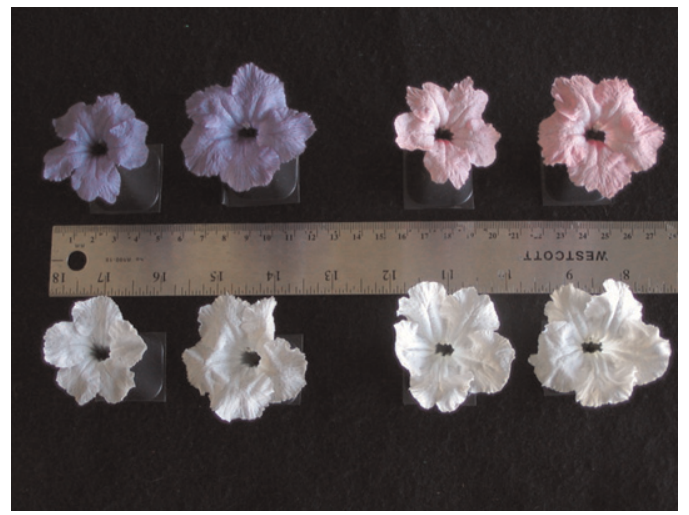

Fig. 2. Flower size and color of diploid (left) and tetraploid (right) Ruellia purple, pink, white, and white with purple corolla tube (clockwise from top left).

(such as R8-100), and some had a more complex parentage (such as R10-108). Tetraploid R10-105 was obtained from a $4 x \times 2 x$ cross using diploid 'Chi Chi' as a paternal parent, which either suggests apomixis on the maternal parent or that 'Chi Chi' produces functional $2 n$ pollen. R10-106 was obtained from a white $4 x \times$ pink $2 x$ cross, and it was white rather than the expected pink color, again indicative of apomixis on the maternal parent. The selected plants with white flowers with purple center were obtained directly by selection of McKee $F_{1}$ progeny or from seedlings treated with oryzalin.

Field performance. All three sites had similar weather patterns and did not deviate significantly from the 10-year average, except for total rainfall at Fort Pierce, which was high during the months of August to October. There were highly significant differences $(P<0.0001)$ for landscape performance, flowering, and fruiting for weeks, sites, plants, and all of the interactions, whereas the differences between blocks were not significant (data not shown). Average landscape performance for all plants was 3.3 at northwestern, 3.5 for north-central, and 3.6 for southeastern Florida (Table 4). This may be the result of different environmental conditions, a longer establishment period needed as a result of initial cooler temperatures, and a more rapid plant decline in the northernmost site as evidenced by the lower ratings from Weeks 16 to 24 (data not shown). Averaging over the three sites, the highest landscape performance rating was on Week 8 (4.0) followed by Week 12 (3.8) and Week 16 (3.5).

Table 2. Number of $4 x \times 2 x$ and $2 x \times 4 x$ hybridizations performed with Ruellia plants, number of fruits formed and harvested, number of seeds germinated, and number of $2 x, 3 x$ and $4 x$ seedlings obtained.

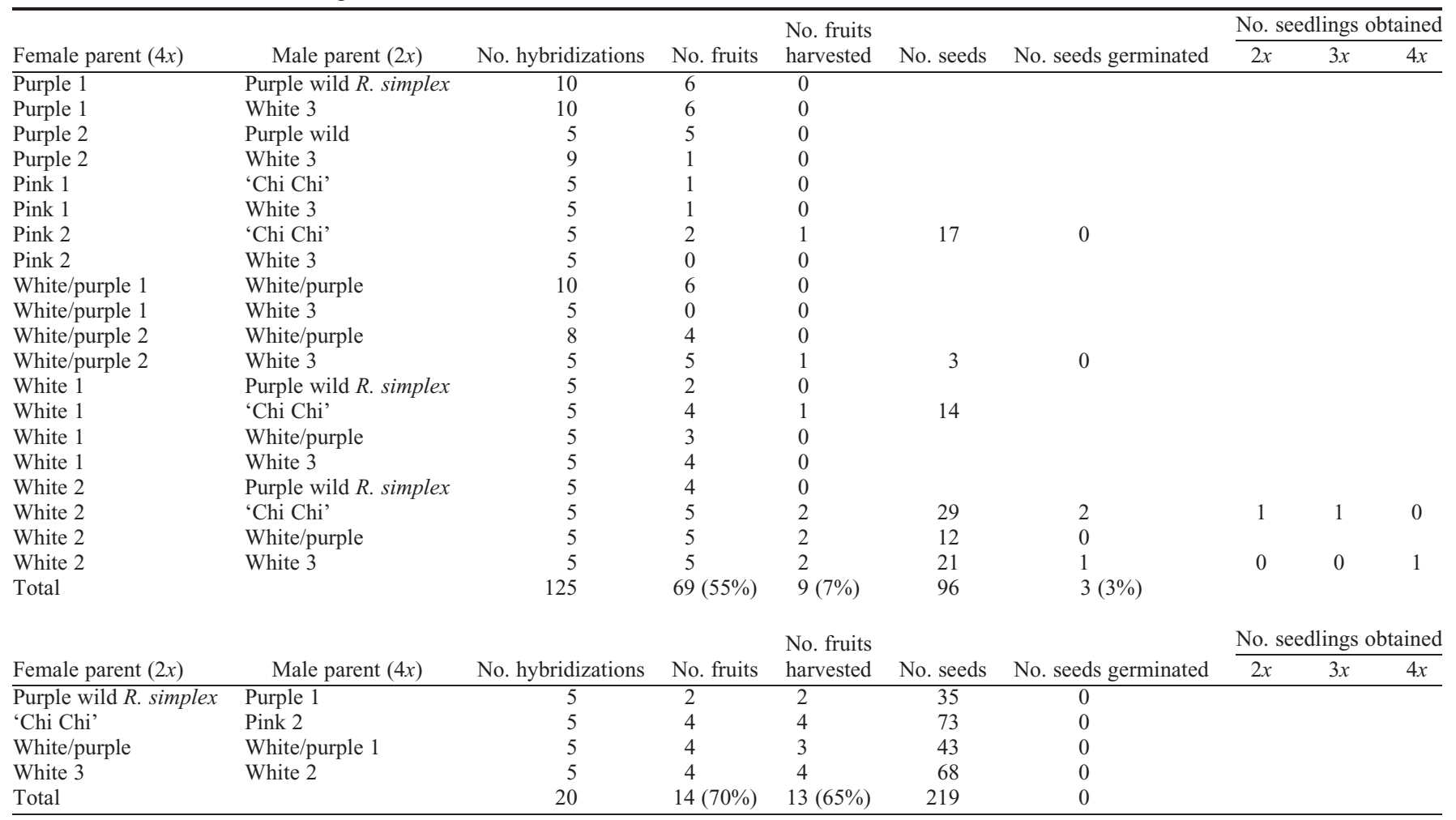


Table 3. Characteristics and origin of 15 selected Ruellia plants and five controls included in the 2011 summer field trial at northwestern, north-central, and southeastern Florida.

\begin{tabular}{|c|c|c|c|c|c|}
\hline Plant & Flower color & Ploidy & Maternal parent & Paternal parent & Origin/notes \\
\hline $\begin{array}{l}\text { Purple wild } \\
\quad \text { R. simplex }\end{array}$ & Purple & $2 \mathrm{x}$ & Unknown & Unknown & $\begin{array}{l}\text { Collected from naturalized } \\
\text { populations in Fort Pierce, FL }\end{array}$ \\
\hline 'Purple Showers' & Purple & $4 \mathrm{x}$ & Unknown & Unknown & $\begin{array}{l}\text { Commercial cultivar, } \\
\text { Riverview Farms, Seffner, FL }\end{array}$ \\
\hline R10-100 & Purple & $3 x$ & $\begin{array}{l}\text { White } \\
\quad \text { oryzalin-treated } \\
\text { R. simplex }(4 \mathrm{x})\end{array}$ & 'Chi Chi' & $\mathrm{F}_{1}$ line bred in 2010 \\
\hline R10-102 & Purple & $4 \mathrm{x}$ & $\begin{array}{l}\text { Purple } \\
\text { South American } \\
\text { R. simplex }(4 \mathrm{x})\end{array}$ & Pink oryzalin-treated $R$. simplex $(4 \mathrm{x})$ & $\mathrm{F}_{1}$ line bred in 2010 \\
\hline 'Chi Chi' & Pink & $2 \mathrm{x}$ & Unknown & Unknown & $\begin{array}{l}\text { Commercial cultivar, } \\
\quad \text { Grandiflora, Gainesville, FL }\end{array}$ \\
\hline 'Snow White' & White & $4 \mathrm{x}$ & Unknown & Unknown & $\begin{array}{l}\text { Commercial cultivar, } \\
\text { Grandiflora, Gainesville, FL }\end{array}$ \\
\hline R8-100 & White & $2 \mathrm{x}$ & Purple wild R. simplex & 'Katie White' & $\mathrm{F}_{2}$ hybrid bred in 2008 \\
\hline R10-106 & White & $4 \mathrm{x}$ & $\begin{array}{l}\text { White ('Snow White' } \times \text { purple } \\
\quad \text { wild } R \text {. simplex) } \mathrm{F}_{2}\end{array}$ & 'Chi Chi' & $F_{2}$ hybrid bred in 2010 \\
\hline R10-107 & White & $8 \mathrm{x}$ & $\begin{array}{l}\text { White ('Snow White' } \times \text { purple } \\
\text { South American } R . \text { simplex) } \\
\mathrm{F}_{1} \text {, oryzalin-treated }\end{array}$ & $\begin{array}{l}\text { Pink oryzalin-treated } \\
\quad \text { R. simplex }(4 \mathrm{x})\end{array}$ & $F_{1}$ hybrid bred in 2010 \\
\hline R10-108 & White & $4 \mathrm{x}$ & $\begin{array}{l}\text { White (purple wild R. simplex } \times \\
\text { 'Katie White') } \mathrm{F}_{2} \text {, } \\
\text { oryzalin-treated }(4 \mathrm{x})\end{array}$ & $\begin{array}{l}\text { White ('Snow White' } \times \\
\quad \text { purple South American R. simplex) } \mathrm{F}_{2}\end{array}$ & $\mathrm{~F}_{2}$ hybrid bred in 2010 \\
\hline McKee & $\begin{array}{l}\text { White/purple } \\
\text { center }\end{array}$ & $2 \mathrm{x}$ & Unknown & Unknown & $\begin{array}{l}\text { Collected at McKee } \\
\text { Botanical Garden, } \\
\text { Vero Beach, FL }\end{array}$ \\
\hline
\end{tabular}

Table 4. Average landscape performance for 15 Ruellia selected plants and five controls in the 2011 summer field trial at three field sites in Florida.

\begin{tabular}{lcccc}
\hline & \multicolumn{3}{c}{ Location } & \\
\cline { 2 - 4 } Plant & Northwestern & North-central & Southeastern & Overall \pm SD \\
\hline Wild $R$. simplex & $3.6^{z} \mathrm{c}^{\mathrm{y}}$ & $3.7 \mathrm{~cd}$ & $3.6 \mathrm{ef}$ & $3.6 \pm 0.3$ \\
'Purple Showers' & $3.3 \mathrm{~d}$ & $3.7 \mathrm{~cd}$ & $3.3 \mathrm{~g}$ & $3.4 \pm 0.3$ \\
R7-100 & $3.7 \mathrm{bc}$ & $3.1 \mathrm{fg}$ & $4.4 \mathrm{bc}$ & $3.7 \pm 0.3$ \\
R10-100 & $2.8 \mathrm{efg}$ & $2.9 \mathrm{fg}$ & $3.1 \mathrm{gh}$ & $3.0 \pm 0.3$ \\
R10-101 & $4.1 \mathrm{a}$ & $4.3 \mathrm{a}$ & $4.3 \mathrm{c}$ & $4.2 \pm 0.3$ \\
R10-102 & $4.0 \mathrm{ab}$ & $4.4 \mathrm{a}$ & $4.5 \mathrm{ab}$ & $4.3 \pm 0.3$ \\
'Chi Chi' & $3.6 \mathrm{c}$ & $3.9 \mathrm{bc}$ & $3.6 \mathrm{ef}$ & $3.7 \pm 0.3$ \\
RU3-100 & $2.9 \mathrm{efg}$ & $3.5 \mathrm{de}$ & $3.9 \mathrm{de}$ & $3.4 \pm 0.3$ \\
R10-103 & $3.7 \mathrm{bc}$ & $4.2 \mathrm{ab}$ & $3.6 \mathrm{f}$ & $3.8 \pm 0.3$ \\
R10-104 & $4.0 \mathrm{ab}$ & $4.2 \mathrm{ab}$ & $3.9 \mathrm{~d}$ & $4.0 \pm 0.3$ \\
R10-105 & $3.8 \mathrm{abc}$ & $4.4 \mathrm{a}$ & $3.8 \mathrm{def}$ & $4.0 \pm 0.3$ \\
'Snow White' & $2.9 \mathrm{defg}$ & $3.3 \mathrm{def}$ & $-1.3 \pm 0.3$ \\
R8-100 & $2.4 \mathrm{~h}$ & $2.4 \mathrm{~h}$ & $2.0 \mathrm{i}$ & $2.3 \pm 0.3$ \\
R10-106 & $3.2 \mathrm{de}$ & $3.0 \mathrm{fg}$ & $3.3 \mathrm{~g}$ & $3.2 \pm 0.3$ \\
R10-107 & $3.1 \mathrm{def}$ & $3.0 \mathrm{fg}$ & $3.3 \mathrm{~g}$ & $3.1 \pm 0.3$ \\
R10-108 & $4.2 \mathrm{a}$ & $4.3 \mathrm{a}$ & $4.6 \mathrm{a}$ & $4.4 \pm 0.3$ \\
McKee & $2.7 \mathrm{fg}$ & $2.3 \mathrm{hi}$ & - & $2.5 \pm 0.3$ \\
R9-105 & $2.9 \mathrm{efg}$ & $2.0 \mathrm{i}$ & $3.2 \mathrm{gh}$ & $3.0 \pm 0.3$ \\
R10-110 & $2.6 \mathrm{gh}$ & $3.0 \mathrm{fg}$ & $2.9 \mathrm{~h}$ & $2.9 \pm 0.3$ \\
R10-111 & $2.8 \mathrm{fg}$ & $3.2 \mathrm{efg}$ & $3.1 \mathrm{gh}$ & $3.0 \pm 0.3$ \\
Overall \pm sD & $3.3 \pm 0.3$ & $3.5 \pm 0.3$ & $3.6 \pm 0.3$ & \\
\hline
\end{tabular}

${ }^{\mathrm{z}}$ Scale from 1 to 5 where 1 = very poor quality, not acceptable, severe leaf necrosis or chlorosis, poor form; 2 = poor quality, not acceptable, large areas of necrosis or chlorosis, poor form; 3 = acceptable quality, somewhat desirable form and color; 4 = very good quality, very acceptable and desirable color and form; $5=$ excellent quality, perfect condition, premium color and form.

yLetters represent Duncan's multiple range test for mean comparisons by site at the $P=0.05$ level.
By Weeks 20 and 24, some tall plants were lodging, had disease issues or less flowering, and more fruits, so ratings declined. The average and SD for landscape performance for the 15 plants and five controls at the three sites over the course of 24 weeks is shown in Table 4. For plants with purple flowers, R10102 and R10-101 performed better than 'Purple Showers' and the purple wild $R$. simplex. Pinks R10-103, R10-104, and R10105 all had better performance than ' $\mathrm{Chi}$ Chi'. White R10-108 had excellent performance at all sites, significantly better than 'Snow White'. All the plants with white corolla with purple center had low performances, although R9-105 and R10-111 were better than McKee.

Average flowering was similar at all sites, northwestern (3.2), north-central (3.3), and southeastern FL (3.5) (Table 5). Averaging over the three sites, flower ratings were highest on Weeks 12 and 16 (4.2) and then declined by Week 24 (3.2). For plants with purple flowers, higher flowering was seen for R7-100, 'Purple Showers', R10-102, and R10-101 (4.1, 3.9, 3.9, and 3.8, respectively). Interestingly, for triploid R7-100, this did not translate into a high landscape performance 
as well (3.7). Of the pinks, diploid RU3-100 had the best flowering (3.8) followed by 'Chi Chi' and R10-105 (3.3 and 3.1, respectively). White R10-108 had excellent flowering (4.0), whereas all the plants with white corolla with a purple center were medium $(\approx 3)$.

Average fruiting was similar at all three sites, ranging from 3.9 to 4.2 (Table 6). For this trait the highest rating of 5 is for no fruits, which is considered the most desirable selection criteria. When transplanted, none of the plants had fruits; thus, the average fruit rating was 5 , but by Week 4 , some plants already had fruited and the rating declined to 4.5. Plants had more fruits and consequently

decreasing fruit ratings as the weeks progressed (3.3 on Week 24). All the selected purple plants were basically fruitless, comparable to 'Purple Showers' and significantly better than the invasive purple wild $R$. simplex. All the selected pink plants had significantly less fruiting than 'Chi Chi'; however, their fruiting ranged between 3.6 to 4.6. White R8-100 and R10-108 were fruitless, whereas 'Snow White' had an average fruiting of 3.3. All the selected plants with white corolla with a purple center had fruiting ranging from 3 to 4.1 .

Overall, two selected plants were outstanding and have potential as new, tetraploid cultivars: purple-flowered R10-102 and white R10-108. They had better landscape

Table 5. Average flowering for 15 Ruellia selected plants and five controls in the 2011 summer field trial at three field sites in Florida.

\begin{tabular}{|c|c|c|c|c|}
\hline \multirow[b]{2}{*}{ Plant } & \multicolumn{3}{|c|}{ Location } & \multirow[b]{2}{*}{ Overall $\pm \mathrm{sD}$} \\
\hline & Northwestern & North-central & $\overline{\text { Southeastern }}$ & \\
\hline Wild $R$. simplex & $3.5^{\mathrm{z}} \mathrm{cdef}^{\mathrm{y}}$ & 3.2 cde & $3.2 \mathrm{~cd}$ & $3.3 \pm 0.3$ \\
\hline 'Purple Showers' & $3.9 \mathrm{bc}$ & $4.0 \mathrm{a}$ & $4.0 \mathrm{a}$ & $3.9 \pm 0.3$ \\
\hline R7-100 & $4.3 \mathrm{a}$ & $3.9 \mathrm{ab}$ & $4.2 \mathrm{a}$ & $4.1 \pm 0.3$ \\
\hline R10-100 & 3.3 defg & $3.5 \mathrm{abc}$ & $3.8 \mathrm{ab}$ & $3.5 \pm 0.3$ \\
\hline R10-101 & 3.6 cde & $3.8 \mathrm{ab}$ & $4.0 \mathrm{a}$ & $3.8 \pm 0.3$ \\
\hline R10-102 & $3.8 \mathrm{bc}$ & $4.0 \mathrm{a}$ & $4.0 \mathrm{a}$ & $3.9 \pm 0.3$ \\
\hline 'Chi Chi' & $3.2 \mathrm{efgh}$ & $3.4 \mathrm{bc}$ & $3.4 \mathrm{bcd}$ & $3.3 \pm 0.3$ \\
\hline RU3-100 & $3.6 \mathrm{~cd}$ & $3.9 \mathrm{ab}$ & $4.1 \mathrm{a}$ & $3.8 \pm 0.3$ \\
\hline R10-103 & $2.6 \mathrm{jk}$ & $2.7 \mathrm{efg}$ & $3.1 \mathrm{de}$ & $2.8 \pm 0.3$ \\
\hline R10-104 & $2.5 \mathrm{k}$ & $2.7 \mathrm{efg}$ & $3.2 \mathrm{~cd}$ & $2.8 \pm 0.3$ \\
\hline R10-105 & 3.0 ghij & $3.2 \mathrm{~cd}$ & $3.2 \mathrm{~cd}$ & $3.1 \pm 0.3$ \\
\hline 'Snow White' & $3.0 \mathrm{ghij}$ & $2.8 \mathrm{defg}$ & - & $2.9 \pm 0.3$ \\
\hline R8-100 & 2.9 hijk & 2.8 defg & $2.6 \mathrm{e}$ & $2.8 \pm 0.3$ \\
\hline R10-106 & 3.4 def & $3.1 \mathrm{cdef}$ & $3.3 \mathrm{~cd}$ & $3.3 \pm 0.3$ \\
\hline R10-107 & 2.7 ejk & $2.4 \mathrm{~g}$ & $2.6 \mathrm{e}$ & $2.6 \pm 0.3$ \\
\hline R10-108 & $4.1 \mathrm{ab}$ & $3.8 \mathrm{ab}$ & $4.1 \mathrm{a}$ & $4.0 \pm 0.3$ \\
\hline McKee & 3.1 fghi & $2.6 \mathrm{fg}$ & - & $2.9 \pm 0.3$ \\
\hline R9-105 & $3.2 \mathrm{efgh}$ & $3.0 \mathrm{cdef}$ & $3.7 \mathrm{abc}$ & $3.4 \pm 0.3$ \\
\hline R10-110 & 2.8 hijk & $2.6 \mathrm{fg}$ & $3.0 \mathrm{de}$ & $2.8 \pm 0.3$ \\
\hline R10-111 & 2.9 hijk & 3.7 defg & $3.0 \mathrm{de}$ & $2.9 \pm 0.3$ \\
\hline Overall \pm SD & $3.2 \pm 0.3$ & $3.3 \pm 0.3$ & $3.5 \pm 0.3$ & \\
\hline
\end{tabular}

${ }^{\text {z }}$ Scale of 1 to 5 where 1 = no flowers or buds; 2 = buds but no open flowers; $3=$ one to 10 open flowers; $4=11$ to 20 open flowers; 5 = more than 20 open flowers per plant.

y'Letters represent Duncan's multiple range test for mean comparisons by site at the $P=0.05$ level.

Table 6. Average fruiting for 15 Ruellia selected plants and five controls in the 2011 summer field trial at three field sites in Florida.

\begin{tabular}{|c|c|c|c|c|}
\hline \multirow[b]{2}{*}{ Plant } & \multicolumn{3}{|c|}{ Location } & \multirow[b]{2}{*}{ Overall $\pm \mathrm{SD}$} \\
\hline & Northwestern & North-central & $\overline{\text { Southeastern }}$ & \\
\hline Wild $R$. simplex & $2.5^{\mathrm{z}} \mathrm{f}^{\mathrm{y}}$ & $2.4 \mathrm{~g}$ & $3.2 \mathrm{f}$ & $2.3 \pm 0.2$ \\
\hline 'Purple Showers' & $4.8 \mathrm{a}$ & $5.0 \mathrm{a}$ & $5.0 \mathrm{a}$ & $4.9 \pm 0.2$ \\
\hline $\mathrm{R} 7-100$ & $4.9 \mathrm{a}$ & $4.9 \mathrm{ab}$ & $5.0 \mathrm{a}$ & $4.9 \pm 0.2$ \\
\hline R10-100 & $4.9 \mathrm{a}$ & $5.0 \mathrm{a}$ & $5.0 \mathrm{a}$ & $5.0 \pm 0.2$ \\
\hline R10-101 & $4.9 \mathrm{a}$ & $5.0 \mathrm{a}$ & $5.0 \mathrm{a}$ & $5.0 \pm 0.2$ \\
\hline R10-102 & $4.9 \mathrm{a}$ & $5.0 \mathrm{a}$ & $5.0 \mathrm{a}$ & $5.0 \pm 0.2$ \\
\hline 'Chi Chi' & $2.6 \mathrm{f}$ & $2.7 \mathrm{~g}$ & $2.0 \mathrm{f}$ & $2.4 \pm 0.2$ \\
\hline RU3-100 & $4.5 \mathrm{ab}$ & $4.6 \mathrm{abc}$ & $3.6 \mathrm{~d}$ & $4.2 \pm 0.2$ \\
\hline R10-103 & $3.8 \mathrm{~d}$ & $4.2 \mathrm{de}$ & $4.0 \mathrm{~cd}$ & $4.0 \pm 0.2$ \\
\hline R10-104 & $3.8 \mathrm{~d}$ & 4.3 cde & $3.7 \mathrm{~d}$ & $3.9 \pm 0.2$ \\
\hline R10-105 & $4.3 \mathrm{bc}$ & $4.6 \mathrm{bcd}$ & $4.2 \mathrm{bc}$ & $4.4 \pm 0.2$ \\
\hline 'Snow White' & $3.2 \mathrm{e}$ & $3.5 \mathrm{f}$ & - & $3.3 \pm 0.2$ \\
\hline R8-100 & $4.9 \mathrm{a}$ & $5.0 \mathrm{a}$ & $5.0 \mathrm{a}$ & $5.0 \pm 0.2$ \\
\hline R10-106 & $2.6 \mathrm{f}$ & $3.2 \mathrm{f}$ & $2.3 \mathrm{f}$ & $2.7 \pm 0.2$ \\
\hline R10-107 & $4.7 \mathrm{a}$ & $4.9 \mathrm{ab}$ & $4.4 \mathrm{~b}$ & $4.7 \pm 0.2$ \\
\hline R10-108 & $4.8 \mathrm{a}$ & $5.0 \mathrm{a}$ & $5.0 \mathrm{a}$ & $5.0 \pm 0.2$ \\
\hline McKee & $3.1 \mathrm{e}$ & $3.4 \mathrm{f}$ & - & $3.2 \pm 0.2$ \\
\hline R9-105 & $4.1 \mathrm{~cd}$ & $3.4 \mathrm{f}$ & $3.6 \mathrm{~d}$ & $3.8 \pm 0.2$ \\
\hline R10-110 & $3.7 \mathrm{~d}$ & $3.9 \mathrm{e}$ & $3.3 \mathrm{e}$ & $3.6 \pm 0.2$ \\
\hline R10-111 & $3.8 \mathrm{~d}$ & $4.1 \mathrm{e}$ & $3.0 \mathrm{e}$ & $3.6 \pm 0.2$ \\
\hline Overall \pm SD & $4.0 \pm 0.2$ & $4.2 \pm 0.2$ & $3.9 \pm 0.2$ & \\
\hline
\end{tabular}

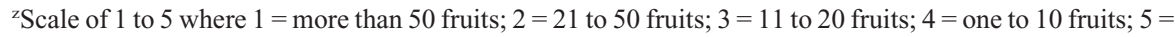
no fruits per plant.

y'Letters represent Duncan's multiple range test for mean comparisons by site at the $P=0.05$ level. performance and flowering than the currently existing commercial cultivars Purple Showers and Snow White, respectively. These two plants combine $R$. simplex germplasm from South America (previously known as $R$. coerulea) and North America (previously known as $R$. tweediana) and have intermediate morphology between the two types. The different morphology and ploidy levels of these two types ( $2 x$ in $R$. tweediana and $4 x$ in $R$. coerulea) argue in favor of their identification as different species rather than the use of the all-encompassing $R$. simplex name.

Both R10-102 and R10-108 are fruitless, so they pose no threat of invasiveness by seed dispersal, and they are also male-sterile so will not pollinate other Ruellia plants. This is most likely the result of hybrid sterility when the two genomes from $R$. coerulea and $R$. tweediana are combined. Sterility in wide hybrids may be the result of lack of chromosome homology resulting in poor or no meiotic chromosome associations between genomes or it may be genic in nature (Stebbins, 1950). Because both R10-102 and R10-108 can be considered allotetraploids having two gene copies from each genome, their meiotic pairing should be normal. This suggests that the cause of the sterility is genic as described by Dobzhansky (1936) and as a result of incompatibility between genetic factors contributed by the two parents. This sterility barrier in the hybrids is further evidence that the former taxonomy, which separated $R$. coerulea and $R$. tweediana into different taxons, is more representative of the genetic relationship between the two species.

\section{Literature Cited}

American Horticultural Society. 1998. PublicationsHeat zone finder. 10 Sept. 2011. <http://www. ahs.org/publications/heat_zone_finder.htm $>$.

Czarnecki, D.M., II and Z. Deng. 2009. Occurrence of unreduced female gametes leads to sexual polyploidization in lantana. J. Amer. Soc. Hort. Sci. 134:560-566.

Daniel, T.F. and T.I. Chuang. 1993. Chromosome numbers of New-World Acanthaceae. Syst. Bot. 18:283-289.

Daniel, T.F., T.I. Chuang, and M.A. Baker. 1990. Chromosome numbers of American Acanthaceae. Syst. Bot. 15:13-25.

Daniel, T.F., B.D. Parfitt, and M.A. Baker. 1984. Chromosome numbers and their systematic implications in some North-American Acanthaceae. Syst. Bot. 9:346-355.

Dobzhansky, T.H. 1936. Studies on hybrid sterility. II. Localization of sterility factors in Drosophylla pseudoscura hybrids. Genetics 113-135.

Ezcurra, C. 1993. Systematics of Ruellia (Acanthaceae) in southern South America. Ann. Mo. Bot. Gard. 80:787-845.

Ezcurra, C. and T.F. Daniel. 2007. Ruellia simplex, an older and overlooked name for Ruellia tweediana and Ruellia coerulea (Acanthaceae). Darwiniana 45:201-203.

Federov, A.A. (ed.). 1969. Chromosome numbers of flowering plants [in Russian]. Acad. Sci. Leningrad. Reprint by O. Koelz 1974.

Florida Exotic Pest Plant Council. 2011. List of invasive species. Florida Exotic Pest Plant Council. 15 Jan. 2012. <http://www.fleppc.org/ list/2011PlantList.pdf $>$. 
Gann, G.D., K.A. Bradley, and S.W. Woodmansee. 2008. The Floristic inventory of south Florida database online. 26 June 2009. < http://regional conservation.org/ircs/index.asp $>$.

Gilman, E.F. 1999. Ruellia brittoniana, Fact Sheet FPS-513. Environmental Horticulture Department, Florida Cooperative Extension Service, Institute of Food and Agricultural Sciences, University of Florida. 8 July 2007.<http:// edis.ifas.ufl.edu/fp513>.

Grant, W.F. 1955. A cytogenetic study in the Acanthaceae. Brittonia 8:121-149.

Hupp, K.V.S., A.M. Fox, S.B. Wilson, E.L. Barnett, and R.K. Stocker. 2009. Publication ENH1155. Natural area weeds: Mexican Petunia (Ruellia tweediana). Environmental Horticulture Department, Florida Cooperative Extension Service, Institute of Food and Agricultural Sciences, University of Florida. 7 May 2012. <http://edis.ifas.ufl.edu/ ep415>.

IFAS Invasive Plant Working Group. 2011. IFAS Assessment of Non-Native Plants in Florida's Natural Areas. 12 Feb. 2012. <http://plants. ifas.ufl.edu/assessment/pdfs/results.pdf $>$.

Jones J.R., T.G. Ranney, and T.A. Eaker. 2008. A novel method for inducing polyploidy in Rhododendron seedlings. J. Amer. Rhododendron Soc. Summer:130-135.
Kartesz, J.T. 2012. The Biota of North America Program (BONAP). 2012. North American Plant Atlas, Chapel Hill, NC. 22 Feb. 2012. <http:// www.bonap.org/MapSwitchboard.html>.

Li, Y., Z. Cheng, W. Smith, D. Ellis, Y. Chen, X. Zheng, Y. Pei, K. Luo, H. Duan, D. Zhao, and Q. Yao. 2004. Invasive ornamental plants: Problems, challenges and molecular tools to neutralize their invasiveness. Crit. Rev. Plant Sci. 23:381-389.

Ornamental Outlook. 2009. Market Watch: Perennials. 26 May 2009. 5 Mar. 2012. <http://www. ornamentaloutlook.com/news/newsyouneed toknow/?storyid=782>.

Pimentel, D., R. Zuniga, and D. Morrison. 2005. Update on the environmental and economic costs associated with alien-invasive species in the United States. Ecol. Econ. 2:273-288.

Piovano, M.A. and L.M. Bernadello. 1991. Chromosome numbers in Argentinian Acanthaceae. Syst. Bot. 16:89-97.

Randall, J.M. and J. Marinelli (eds.). 1996. Invasive plants: Weeds of the global garden. Brooklyn Botanic Garden Handbook 149.

Ranney, T.G. 2004. Population control: Developing non-invasive nursery crops. Comb. Proc. Intl. Plant Prop. Soc. 54:604-607.

SAS Institute. 2004. SAS for Windows, Version 9.1.3. Cary, NC.
Stebbins C.L., Jr. 1950. Variation and evolution in plants. Columbia Univ. Press., New York, NY.

U.S. Department of Agriculture. 2011. USDA plant hardiness zone map. 12 Jan. 2012. <http:// planthardiness.ars.usda.gov/>.

U.S. Department of Agriculture, Natural Resources Conservation Service. 2012. The PLANTS Database, National Plant Data Center, Baton Rouge, LA. 15 Feb. 2012. <http://www.plants. usda.gov/java/nameSearch?keywordquery= Ruellia\&mode $=$ sciname \&submit. $x=8 \&$ submit. $\mathrm{y}=11>$.

Wilson, S.B. and L.A. Mecca. 2003. Seed production and germination of eight cultivars and the wild-type of Ruellia tweediana: A potentially invasive ornamental. J. Environ. Hort. 21: 137-143.

Wirth, F.F., K.J. Davis, and S.B. Wilson. 2004. Florida nursery sales and economic impacts of 14 potentially invasive ornamental plant species. J. Environ. Hort. 22:12-16.

Witzum, A. and K. Schulgasser. 1995. The mechanics of seed expulsion in Acanthaceae. J. Theor. Biol. 176:531-542.

Wunderlin, R.P. and B.F. Hansen. 2012. Atlas of Florida Vascular Plants Institute for Systematic Botany, Univ. of South Florida, Tampa. 22 Feb. 2012. <http://www.florida.plantatlas.usf.edu/ Results.aspx $>$. 